\title{
DOES BANK RECAPITALIZATION AFFECT THE PERFORMANCE OF THE BANKING SECTOR? THE EMPIRICAL EVIDENCE
}

\author{
MUHAMMED UMAR DIKKO*1,2, MOHD NORFIAN ALIFIAH ${ }^{1}$ AND SANI ABDULLAHI ${ }^{1}$ \\ ${ }^{1}$ Azman Hashim International Business School, Universiti Teknologi Malaysia, 81310 Skudai Johor Bahru, Malaysia. \\ ${ }^{2}$ College of Administration, Department of Banking and Finance, Waziri Umaru Federal Polytechnic Birnin Kebbi, Kebbi \\ State, Nigeria.
}

*Corresponding author: mahdikko@gmail.com

Submitted final draft: 16 May $2020 \quad$ Accepted: 4 July 2020

http://doi.org/10.46754/jssm.2021.04.013

\begin{abstract}
Over the last decade, financial institutions, especially the banking sector across emerging markets, have been faced with forceful recapitalizations as a result of numerous global financial crises. The study aims to investigate the effect of bank recapitalization approaches such as mergers and acquisitions, equity issues and interventions (bailouts) on the performance of the Nigerian banking sector. The notion that bank recapitalization heats up has been discussed and still does not present a proper consensus in the available literature. Therefore, topics that involve research on the strategies of recapitalization and their effects on bank performance are of interest in the literature. A survey method was used to gather data and the responses received from the regional, branch and senior managers in the banking sector were used to analyse and check to see if bank recapitalization actually affects the performance of the banking sector. Structural equation modelling (SEM) results indicated that bank recapitalization is positively related to bank performance. The results further revealed that all the recapitalization approaches have a positive and significant effect on bank performance. Thus, the use of recapitalization mechanisms for undercapitalized banks during crises or normal times is highly encouraged for sustainability and in the banking sector, as the backbone of the economy of any nation. Further suggestions for future research directions are also offered.
\end{abstract}

Keywords: Bank recapitalization, bank performance, sustainable banking sector, merger and acquisition.

\section{Introduction}

Banks are a critical part of the financial system of any country and plays an important role in ensuring sustainable economic growth and development. It is generally believed that the financial stresses that emerged in 20072008 were due to unexpectedly high mortgage delinquencies eventually led to the banking sectors of many countries being frozen out of short-term funding and consequently led to a global financial crisis (GFC). Fernandes et al. (2016) advocated that the GFCs of the last decade were the most serious crises since the Great Depression in 1940. The GFC in 2007-2009 has raised key concerns about the effectiveness and stability of the banking sector in many countries (Al-Magharem et al., 2019; Ashraf et al., 2020). The imminent failure of many banks necessitated the intervention of governments all over the world to enact laws and carry out a variety of rescue operations to prevent wide-scale banking collapse. These interventions included (i) direct capital injections, (ii) liquidity support to banks, (iii) purchases of distressed "toxic" assets by world governments, (Fernandes et al., 2016).

Bank regulators believe that having higher capital levels can help the banking sector increase the loss absorption capacity and enhance their odds of surviving another GFC (Berger \& Bouwman, 2013). In view of this, neither developed nor developing countries had any experience or method for dealing with their banking sector recapitalization and how it affects individual banks' performance. For instance, the bank recapitalization experience gained by Malaysia, Indonesia, and Thailand 
were a direct result of the 1997 Asian financial crisis (Sufian \& Shah 2013; Etri et al., 2016; Ernovianti \& Ahmad, 2017). Similarly, the United States (US) and some other European countries learned about banking recapitalization as a direct response to the 2007-2008 GFC (Georgakopoulos, 2017; Tomec \& Jagrič, 2017).

Similarly, in Nigeria, it was observed that the poor managerial performance and poor corporate governance had been recognized as major culprits of the distress suffered by the banking system, in the country, which led to the banks recapitalization reform in 2004 and subsequently, the recapitalization of specialized banks in December 2007 (CBN, 2010; Sanusi, 2010; Acha, 2012). The repercussions of the banking sector recapitalization reform in Nigeria resulted to the implementation of several strategies, with many banks engaging in mergers and acquisitions and the capital market (equity issues) (Izuchukwu et al., 2014).

Moreover, other banks resorted to bailout to be able to meet the new capital base (Shehu et al., 2014; Rapiah et al., 2016). According to Soludo (2004) 89 banks were categorized by low capital base, poor asset quality, overdependence on public sector deposits and weak corporate governance. This lead to a massive recapitalization exercise through mergers and acquisitions, which saw the 89 banks trimmed down to 25 banks as at June 2005 (Ezeoha, 2011).

This, in turn, led to the regulatory authorities such as Central Bank of Nigeria (CBN) and the Nigeria Deposit Insurance Corporation (NDIC)) carrying out a special examination of all banks in Nigeria in July 2009, with the aim of assessing their state of health, with particular focus on capital adequacy, risk management, liquidity and corporate governance practices (Chiakelu, 2010; NDIC, 2011; Oleka \& Mgbodile, 2014).

In addition, 10 banks were adjudged to be in grave state with deficiencies in capital adequacy, and 8 of them also had significant deficiencies of liquidity and corporate governance policies whereas, the aggregate of a non-performing loan of these banks was 40.81\% (CBN, 2010; Sanusi, 2011). Moreover, the executive directors (ED) of these eight banks were suspended, and all the 10 banks received bail-outs in the form of injection of fresh capital to the tune of $\$ 620$ billion, in the form of Tier two Capital intervention (CBN, 2010; Sanusi, 2010; Alford, 2011; Shehu et al., 2014). The Nigerian banking industry was recently rocked by furhter tragedy following the recent collapse of 183 financial institutions, which included 154 are microfinance banks, and six primary mortgage banks, a list released by the financial regulators showed (Odunsi, 2018; Rilwan, 2018).

Even with the importance of the banking sector in regulating and stabilizing the economy, many empirical studies concerning the relationship between recapitalization and the performance of banks appeared to be mixed or have weak findings. No consistent result can be identified especially given the limited number of studies available for review. For instance, some studies found bank recapitalization or its proxies to be positively related to performance (Bhagat et al., 2011; Bhaumik \& Selarka, 2012; Yusupov, 2012; Ding et al., 2013; Nicholson \& Salaber, 2013; Beccalli \& Frantz, 2016; Etri et al., 2016; Donou-Adonsou \& Sylwester, 2017; Ernovianti \& Ahmad, 2017). Others observed a negative relationship (Aybar \& Ficici, 2009; Bertrand \& Betschinger, 2012; Beccalli et al., 2016; Tomec \& Jagrič, 2017). Some studies also found that bank recapitalization are unrelated to bank performance (Liao \& Williams, 2008; Adedeji et al., 2015).

Furthermore, most research conducted globally and in Nigeria in particular, have some other kind of shortcoming, which results in unusual or conflicting findings, inconsistency, limited scope, inconvenient samples, and are usually focused on a single mechanism or approach of recapitalization and performance, and therefore neglect other important mechanisms through roles and strategic initiatives. 
Among the common methods of measuring recapitalization, this study used a reputation index suggested by Moskowitz (1972), Islam et al. (2012), to measure recapitalization in Nigeria. This study also developed a questionnaire and asked knowledgeable observers to rate the bank on three dimensions of recapitalization (Coates \& Scharfstein 2009).

In addition, the over-reliance on traditional measures of financial performance alone (i.e., return on asset (ROA), return on investment (ROI), return on equity (ROE), operating profit, market share, turnover rate, etc.) are considered as insufficient performance measurement indicators and may not provide a clear picture of performance or may not fetch any competitive advantage for a company's performance (Kaplan \& Norton, 1996; Saeidi et al., 2014; Adebambo et al., 2015; Ahmed \& Manab, 2016).

Moreover, the addition of non-financial performance metrics can efficiently and effectively assist the company in assessing the overall performance visibly and tend to be a better predictors for future performance (Kaplan \& Norton, 1996; Hussain \& Hoque, 2002; Potter \& Srinivasan, 2005).

This study proposes a framework that selects the most appropriate variables best to address recapitalization and banks' performance problems peculiar to Nigeria.

In addition, this study would adapt the multiple criteria used in a balanced scorecard based on the four perspectives which are more objective and comprehensive than a single measure (Kaplan \& Norton 1996).

Therefore, the indexes considered are those fit for banking performance evaluation selected through expert questionnaires (Wu et al., 2009). Additionally, the outcome of this paper shall be of immense importance to academics, regulators, shareholders, and policymakers, as it examines the effects of bank recapitalization and its approaches on the performance under a similar context of the Nigerian banking sector as the motivation, is needed to address the aforementioned research gap.

\section{Concept of Recapitalization on Bank Performance}

Many researchers defined recapitalization from a different perspective. For instance, Etri et al. (2016) described recapitalization as a rescue plan by the central bank of a country through capital injections and the acquisition of weaker banks by stronger banks.

Recapitalization was also defined as a change in the capital structure of a company or an organization (Aduloju et al., 2008). In agreement with Basel capital requirements, most of the empirical studies argued that bank recapitalization improves banking efficiency, the role of traditional lending of banks and allows banks to increase the ability to withstand economic pressures, thereby providing a sustainable banking sector and international business (Francis et al., 2012; Berger \& Bouwman, 2013; Repullo \& Suarez, 2013).

Similarly, Ashraf et al. (2016) reported that the adoption of Basel-III committee on banks capital requirements, both the quantity and quality of banks capital requirements in response to 2007-2009 GFC have been significantly improved.

Petrovic and Tutsch (2009) also suggested that the distressed banks with a view to capital restructuring can involve in either private or public recapitalization.

Beccalli \& Frantz, 2016 have extensively discussed the main motivation for private recapitalizations, is to reduce risk-taking hypothesis through solvency risk to achieve the existence of better operating performance. However, the motivation for banks' public recapitalization is associated with the larger size, lower liquidity, and higher growth at the bank level but lower growth rate at the country level while the state intervention happens in more difficult situations where private solutions are not possible (Beccalli \& Frantz, 2016).

Meanwhile, Berger and Bouwman (2013) revealed that capital helps small banks to increase their market share and probability of survival at all times during normal times, and 
banking crises (Berger \& Bouwman, 2013). The authors further revealed that capital enhances the performance of medium and large banks, primarily during global financial crises.

\section{Recapitalization Approaches}

Based on the previous literature, Adedeji et al. (2015) also reported that the strategies in recapitalization include mergers and acquisitions, which will lead to the external growth of a company. However, Coates and Scharfstein (2009) rather than private investment, and on bank holding companies, rather than banks. We describe three alternative or complementary approaches designed to lower the cost of bank recapitalizations by drawing in funds from the private sector and focusing on banks: rights offerings, debt restructurings, and FDIC-assisted bridge banks. Each approach was used in dealing with problem banks in the 1990s; each can be pursued without additional legislation; and each is worth considering now. We also propose two legal changes that would assist bank recapitalization: (1 reported that the bank's recapitalization has three basic approaches, through either equity issue which comprised public offering and private placement, intervention, and sales of banks (merger and acquisition) as shown in Table 1.

\section{Bank Performance}

Antony and Bhattacharyya, 2010 defined performance as the measure used to assess and evaluate the success of an organization to create and deliver the value to its external as well as internal customers. Moreover, Abdul-Rasheed et al. (2012) described performance as the capacity of banks to maximize returns on investors' funds. It is a measure of a company's operations and policies in monetary terms. These results are reflected in the company's return on assets, return on investment, capital base, value-added, employee's performance and customer loyalty ( Mishkin, 2007; Gitau \& Samson, 2016).

Furthermore, El-Chaarani and El-Abiad (2019) used ROA and ROE to measure the performance of the banking sector in Middle Eastern Countries. In addition, Neely (2007) reported that there are numerous financial measures, but the most commonly used are ROE, ROA, ROI, the value per employee, earnings per share and net profit margin. However, financial performance used to be very popular for measuring the performance of an organization, but now they are no longer seen as adequate means of measuring performance due to some of their weaknesses.

Moreover, the weakness of traditional accounting measures of performance are well documented in the literature and include failing to convey strategies and priorities effectively within an organization (Najmi et al., 2005). This view was supported by many researchers who stressed that in the service sector like the banking industry, it is necessary to use the multidimensional measurements of performance (Kaplan \& Norton, 2001; Hussain \& Hoque, 2002; Bremser \& Chung, 2005; Wu et al., 2009).

Recently due to the highly competitive business environment, the quest for survival and sustainability forced the adoption of nonfinancial performance measures in addition to

Table 1: Approaches in the recapitalization

\begin{tabular}{lll}
\hline S/N & \multicolumn{1}{c}{ Authors and year } & \multicolumn{1}{c}{ Approaches of Recapitalization } \\
\hline 1 & Adedeji et al. (2015) & 1. Merger and Acquisition \\
2 & Coates and Scharfstein (2009) & 2. Equity issues \\
& & a. Initial public offering \\
& & b. Private placement \\
& & 3. Intervention \\
\hline
\end{tabular}

The basic strategies used by previous authors to measure recapitalization. 
financial performance measures (Rapiah et al., 2016). This is because non-financial measures enable business process improvement, learning and innovation and customer satisfaction. All these are significant determinants of a company's growth and profitability (Rapiah et al., 2016). Kaplan and Norton, (1996) invented the Balanced Scorecard (BSC) framework that consists of both financial and non-financial performance measures which serve as an indicator used in monitoring strategy implementation all over the organization and also determine if strategy objectives were achieved or not (Bremser \& Chung, 2005). The BSC provides an excellent system for performance measurement in the banking industry (Bremser \& Chung, 2005). In addition, $\mathrm{Wu}$ et al. (2009) used the BSC framework and proposed a Fuzzy Multiple Criteria Decision Making (FMCDM) approach for banking performance evaluation.

The researcher synthesized and summarised from the literature relating to the bank's performance and selected some indexes fit for banking performance evaluation that include both financial and non-financial measures through the expert questionnaires. Hence, this study adapted the Wu et al. (2009) banking performance indexes derived from BSC to measure the performance of the banking industry.

\section{Research Structural and Hypothesis Development}

Inadequate capital has been described as among the main factor that contributed to the banking crisis (Acharya \& Steffen, 2015)Italy, Ireland, Portugal, Spain, or GIIPS. Rhoades (1996) revealed that having essential effects on the banking sector and the economy, the United financial crisis had a significant impact on financial institutions and banks all over the world faced with the liquidity problems which led to the recapitalization of the affected banks by their respective countries.

The financial crisis after the Lehman shock in 2008 and the global recession that followed forced the developed countries such as England, the US, France, Germany, Ireland, and Switzerland to implement programs such as bank recapitalizations (Nakashima, 2016). There is no empirical consensus on whether it had produced the desired results or not, but the policy has been extended to the emerging economy (Nakashima, 2016).

\section{The Relationship between Merger and Acquisition and Bank's Performance}

The extant empirical research may have addressed the relationship between merger and acquisition and bank performance. However ityet remains unclear, because of mixed results from empirical studies (Lebedev et al., 2015). Souza and Gartner (2019) reported that in the most recent times, the global economy, particularly in the banking sector, has realized an increase in the incidence of mergers and acquisitions. Some researchers argued that cross-border investment could lead to the inflows of capital and do not only bring in the needed capital but have positive implications on productivity and investment that can improve the host country's business performance (Miozzo et al., 2016).

This is specifically important for developing economy firms, which usually face financial constraints that shorten their ability for project enhancements to upgrade the existing facilities which consequently improve the performance.

For instance, Christine and Jagongo (2018) investigated and theorized the performance of merger and acquisition in a few select banks in Kenya and revealed that risk diversification, differential efficiency, operational synergy, market share development of merger and acquisition have significantly improved performance. This result is in agreement with the finding of Hassen et al. (2018) who also revealed that the operations of mergers and acquisitions are needed for the necessary growth of banks to increase the scale of returns.

These study findings are also similar to Abdulazeez et al. (2016) which revealed that merger and acquisitions led to improved 
and robust performance and efficiency in the Nigerian banking sector. There are some other similar studies that revealed cultural affinity, local experience and geographical proximity of a bidding firm of merger and acquisition had significantly increased the probability of completing the deal which significant increases the operating performance (Arena \& Dewally, 2017).

Meanwhile, Souza and Gartner (2019) reported that there is a significant positive relationship between mergers and acquisitions and bank performance because banks involved in merger and acquisition leading to market gains and greater market power for acquiring banks and increases abnormal returns for newly merged acquiring bank. Furthermore, many previous researchers have conducted the empirical analysis on the relationship of merger and acquisition and bank's performance, and they found merger and acquisition have significantly and positively improved bank performance (Shanmugam \& Nair, 2004; Kiliç, 2011; Meghouar \& Sbai, 2013; Joash \& Njangiru, 2015; Patel, 2018).

On the other hand, Patel (2018) studied the impact of merger and acquisition on the banks' performance and found that ROA, ROE, net profit ratio, the yield on investment and yield on advance has negatively affected the banks performance. In another similar study of the impact of merger and acquisition on performance found mergers and acquisitions negatively affected performance were merger deals failed to improve performance and the results showed a decrease in profitability levels (Kemal, 2011; Lakstutiene et al., 2015; Vulanovic, 2017).

Based on the detailed information in this study. The following hypothesis is proposed:

$\mathbf{H}_{\mathbf{1}}$ : That Mergers and Acquisitions have a positive effect on bank performance.

\section{The Relationship between Equity Issues and the Bank's Performance}

The recent 2007-2008 GFC has triggered the extensive debate on how banks can source capital to prevent banking failure. Much research on bank capital adequacy revealed that capital has a significant impact on a banks' performance (Acharya et al., 2012; Black \& Hazelwood, 2013; Bessler \& Kurmann, 2014; Haggège et al., 2017). Bessler and Thies (2007) also argued that firms with abnormal returns or performances are those with an opportunity to raise additional funds in the equity market through a subsequent seasoned equity offering in the subsequent years.

Equity issues in banks are generally encouraged by bank regulators because they believe that a higher level of capital for individual banks can help to achieve a sustainable banking sector while equity issuance demonstrates a bank's commitment to achieving a certain level of sustainable bank performance (Keeley, 1989).

Moreover, Beccalli et al. (2018) studied bank's behaviour on equity issues with respect to bank recapitalization and found that equity issues lead to asset expansion, reduced systemic risk, increased profitability, increased loan reserves and positive bank performance. However, Aman and Miyazaki (2009)our results indicate that abnormal returns are, on average, positive but statistically insignificant. Such findings fail to support the notion that private placements help resolve the problem of information asymmetry. However, after controlling for bank capital, the valuation effects for banks with higher capital are significantly negative, whereas those with lower capital are significantly positive. The difference suggests that valuation depends on whether capital regulation motivates the new issue. Moreover, there is a negative correlation between Nonperforming Loans (NPLs evaluate the effects of equity issues of some banks in Japan and found contradictory results that equity issues have a significant negative effect on bank performance more especially banks with sufficient capital. Furthermore, Adepoju (2013) reported that the equity issues (stock market) performance of all the sampled banks in his study declined, more especially those financially weak or troubled banks showed greater weakness in stock market performance than the healthy ones. The second hypothesis is as follows: 
$\mathbf{H}_{2}$ : Equity issues have a positive effect on bank performance.

\section{The Relationship between Intervention and Bank's Performance}

Governments worldwide have launched an extraordinary assisted measures for banks in developed economy Rose and Wieladek (2012), De-Caux et al. (2017), and emerging economy (Shehu et al., 2014). In recent time, the authorities all over the world designated for supervision and regulating the banking sector have resolved to a different rescue measures such as extended liquidity support, nationalization of banks, capital injection and blanket guarantees (Bayazitova \& Shivdasani, 2012; Duchin \& Sosyura, 2014; Berger et al., 2016).

Moreover, the effect of the bank's interventions on the bank's performance depends on the type of mechanisms applied by the authorities to assist the banks in preventing failure (Dam \& Koetter, 2012). Theoretical and empirical findings on government interventions from various researchers present mixed results. The major argument advanced by the supporters of intervention is that the regulatory arrangements are necessary to restore the confidence in the banking sector and thereby preventing the sector from falling into prolonged economic recession and they are of the opinion that interventions have positively affected the banking sector performance (Cordella \& Yeyati, 2003; Philippon \& Schnabl, 2010; Mehran \& Thakor, 2011; Hryckiewicz, 2014; Berger et al., 2016).

Furthermore, Mehran and Thakor (2011) and (ii argue that banking intervention is likely to strengthen the monitoring incentives of banks, which consequently improves performance.

However, other studies on interventions came up with the opposite results. They argued that bank intervention causes the banking sector more harm than good. Flannery (1998) reported that bank interventions increase moral hazard due to the anticipations of bailouts and a decline in a market discipline, which negatively affects the bank's performance. Other researchers also argue that such action of bank intervention increases the risk faced by non-assisted banks and also undermines the competition in the banking sector (Gropp, et al., 2011). Duchin and Sosyura (2012) documented that government interventions only favoured those banks that are politically connected because they are more likely to receive financial support than the others, which will undermine the performance of the banking sector. Hence, this study hypothesizes that:

$\mathbf{H}_{3}$ : Intervention has a negative effect on bank performance.

\section{The Relationship between Recapitalization and Bank's Performance}

Although over the years, the arguments surrounding the paradigms of bank recapitalization and bank performance relationships suggest many controversies that are yet to be systematically addressed, it still remains unclear because of mixed results from empirical studies. Several empirical studies found a non-significant or negative effect on the relationships between bank recapitalization (or its dimensions) and bank performance.

For instance, several studies found significant and positive effects of recapitalization and performance (Bhagat et al., 2011; Bhaumik \& Selarka, 2012; Yusupov, 2012; Ding et al., 2013; Nicholson \& Salaber, 2013; Etri et al., 2016; Beccalli \& Frantz, 2016; DonouAdonsou \& Sylwester, 2017; Ernovianti \& Ahmad, 2017). Conversely, several studies also found a negative relationship between recapitalization (or its dimensions) and bank performance (Aybar \& Ficici, 2009; Bertrand \& Betschinger, 2012; Beccalli et al., 2016; Tomec \& Jagrič, 2017; Bibi et al., 2018). This shows that the conceptual underpinnings surrounding bank recapitalization and bank performance relationships are yet a growing paradox that requires considerable attention. Hence, the final hypothesis is as follows:

$\mathbf{H}_{4}$ : There is a positive relationship between recapitalization and bank performance. 


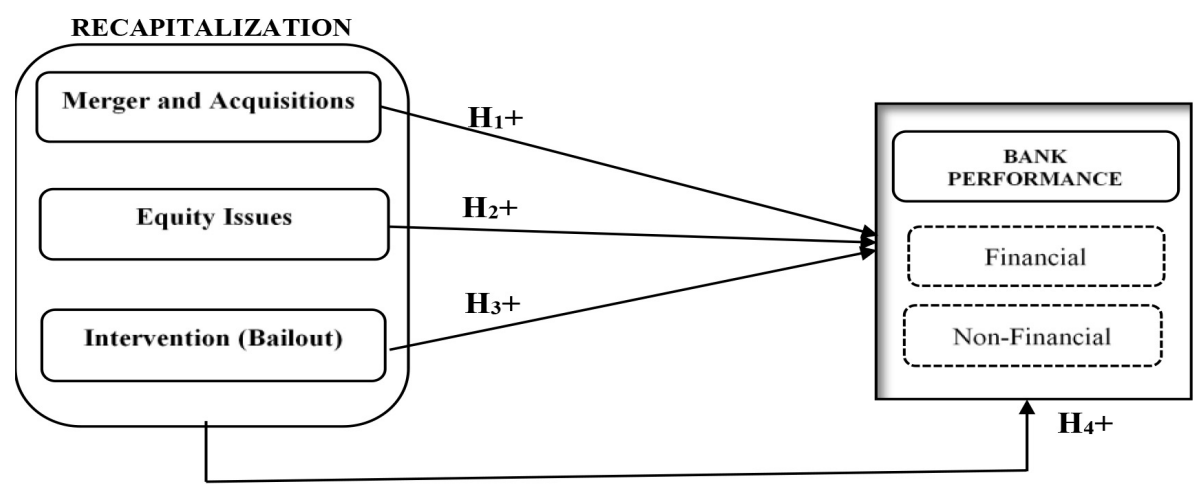

Figure 1: Reserach Model

\section{Methodology}

\section{Instrument}

This study used a self-administered questionnaire prepared in English. A 5-point Likert scale ranging from strongly disagree to strongly agree for exogenous and endogenous variables was employed to rate the top manager's perception of bank recapitalization on the performance of the banking sector. The respondent managers were selected from one of the three top management groups that include regional manager, branch manager or the most senior officer holding a strategic position in the selected sampled bank.

The study utilized measures developed by previous studies to measure the study variables. The recapitalization scale developed by Aduloju et al. (2008) was adapted to measure bank recapitalization framework application in the context of the Nigerian banking sector. The items were anchored on the 5-point Likert scale. Also, measures of financial and nonfinancial performance were adapted from $\mathrm{Wu}$ et al. (2009) which are fit for the banking sectors performance's evaluation. A statement was adopted from Rettab et al., (2009). An example of the statements used include "our ROA has been substantially better or our earnings per share (EPS) has been substantially better" were used throughout the measures of financial and non-financial performance evaluation.

All the items are rated on the 5-point Likert scale from $1=$ strongly disagree to $5=$ strongly agree. All the items adapted were found to be suitable and reliable.

\section{Data Collection}

The stratified sampling method was applied. Stratified sampling has the merit of ensuring equality and fairness in the selection process, especially if the target population are heterogeneous and fall into different segments or groups (Salkind, 2007). Creswell (2014) supported the idea of this stratification as an efficient technique that ensures the sample is distributed in the same manner as the population of the study based on the same stratifying criteria.

Hence the Nigerian banking sector is classified based on two strata; commercial banks (universal banks) and specialized banks which include primary mortgage banks and microfinance banks. In order to obtain a stratified sampling of managers from different banks in each group, this study employed the Krejcie and Morgan's (1970) of sample size determination. This study adopted the cross-sectional method of data collection to answer the study's research questions in which data were collected at once (Salleh \& Nor-Azila, 2018).

The population of this study is 1,079 banks, which comprise of all the universal banks and specialized banks that were affected by a recapitalization between 2006 and 2018. Of the 329 questionnaires sent out, 317 were completed and returned, and 305 were found suitable for analysis. This reflects a $92 \%$ response rate. More importantly, the tool of analysis for the current study, PLS-SEM requires a minimum of only 30 responses (Chin, 1998; thus a total of 305 
responses for this study is adequate for analysis. The $92.7 \%$ response rate is above the minimal range of prevailing response rate. However, some researchers had proposed other minimal level of response rate, causing an inconsistency across the literature concerning acceptable response rate. Babbie (2008) suggested 50 per cent as the minimal level. Groves et al. (2004) and Porter (2004) suggested 60 per cent, while De-Vaus (2002) argued for 80 per cent. Hence, the response rate of this study is adequate for further analysis.

The face and content validity of the questionnaire items were carried out and evaluated by the experts from academia and banking industry. A pilot study was further initiated. Fifty managers were used to conduct a pilot study. This is congruent with the discourse of extant literature that highlighted the appropriateness of 50 participants in a pilot test initiative (Cooper \& Schindler, 2013; Artino et al., 2014; Ogbeibu et al., 2018). Pilot study data was collected from managers of each group. The results of the pilot test were analyzed using SPSS version 25 . The results revealed that eight items out of 44 items loaded below the recommended threshold of 0.60 . Hence, they were dropped (Sarstedt et al., 2014). This reduced the total number of indicator items to 36 .

\section{Statistical Approach}

The choice of this study is driven by the purpose to explore the relationship between the study variables, which concerned exploratory analysis in nature. Smart PLS 3.2.8 was utilized in this exploratory study, and SPSS version 25 was also employed to analyze the descriptive statistics and multicollinearity. The goodness of the model was measured, otherwise known as the measurement model to determine the goodness of the indicators. Assessment of structural model from which our basis of conclusion is done. This model is a reflective-reflective model, and the quality criteria for assessing measurement models are Cronbach alpha and composite reliability which confirms the internal consistency, Average Variance Extracted (AVE) which confirms the convergence validity, and discriminant validity which also consists of Fornell and Larcker (1981) and the heterotraitmonotrait ratio of correlations $\left(\mathrm{HTMT}_{\mathbf{0 . 9 0}}\right)$ (Avkiran, 2018).

\section{Results and Discussion}

\section{Descriptive Statistics of the Respondents}

In this survey study, the respondents comprised of regional managers, $3.3 \%$, branch managers, $44.6 \%$, and senior officers who have the majority of $52.1 \%$. The population included a total of 305 respondents, out of which 251 banks $(82.3 \%)$ were microfinance banks, 35 banks $(11.5 \%)$ were primary mortgage banks and 19 $(6.2 \%)$ were commercial banks.

This demonstrated the efforts made at the global level, which highlighted the financial inclusion strategy developed in Nigeria to decrease the number of Nigerians that are excluded from financial services (Fadun, 2014). The education level outcomes show that 52.8 $\%$ of the total respondents hold a postgraduate degree, which demonstrates that the bank managers and senior officers are a well-educated group in the population. The position distribution of the respondents suggested that $10(3.3 \%)$ are regional managers, while the branch managers represent the significant percentage of $(46.4 \%)$ or 136 individuals while senior managers were represented by 159 individuals $(52.1 \%)$.

As for the years of experience, the managers that served between 11 and 15 years in the banking industry represent by 83 people or 27.2 $\%$ of the sample size, while managers with the banking experience of 16 years and above were the majority as they constituted 222 individuals, or $72.8 \%$ of the entire sample size.

\section{Descriptive Statistics of the Latent Construct}

The descriptive statistics of the latent construct in Table 2 below show the results of the mean and standard deviation. The variables used in this study all have a mean value of 3.96 and above out of 5 , which indicates that the majority of the respondents had a positive opinion in 
agreeing with most of the questions in the survey research. This also denotes that the average response of the respondents agrees with the effect of bank recapitalization implementation within the banking sector.

For the standard deviation, all the scores represented are relatively close to each other. There is not much of a difference between merger and acquisition, equity issues or intervention. It could be inferred that the constructs have been evenly dispersed, thus suggesting the normality of data distribution. For the bank's performance, the mean response has a varied response value of between $34 \%$ and $31 \%$ for financial and non-financial performance, respectively. This implies that the perception of the majority of respondents agreed that the bank's performance significantly improved.

\section{Measurement Model}

There are two main criteria in PLS-SEM evaluation to assess reliability and validity, these were used to evaluate the outer model (Hair et al., 2014). The structural results of the relationship among constructs (inner model) depend on the validity and reliability of the measures. In addition, the measurement model can be evaluated by examining: (i) internal consistency reliability, indicator reliability and individual item reliability using Cronbach's alpha and composite reliability, (ii) convergent validity of the measures assessed by calculating the average variance extracted of the indicators associated with individual constructs Mackenzie et al. (2011), and (iii) discriminant validity using Fornell-Larcker criterion and the indicator's outer loadings, and the heterotrait-monotrait ratio of correlations (HTMT $_{0.90}$ ) which has become a primary criterion for assessing discriminant validity. Figure 3 shows the measurement model of this study.

This study evaluates individual items reliability based on their respective outer loadings and a threshold value $\geq 0.40$ (see table 2) (Hulland, 1999; Hair et al., 2014). Moreover, in some cases, indicators with loadings of between 0.4 and 0.69 were carefully retained on the basis of their contribution to the construct's validity (Avkiran, 2018).

Following the analysis of the correlation matrix for all the exogenous latent variables, this study also conducted an analysis to test for the presence of multicollinearity through variance inflation factors (VIF) and tolerance see Table 2. Hair et al. (2011)SEM is equivalent to carrying out covariance-based SEM (CB-SEM suggested a threshold value of VIF to be less than 5 or even better if it is less than 3 .

In addition, the VIF values for this study were within the range of 1.14 to 1.25 which are less than 3 and are acceptable (Hair et al., 2011). Additionally, Kock (2015) recommends a noteworthy approach for examining common method bias for studies that employed PLSSEM.

The author revealed that the occurrence of a VIF greater than 3.3 is proposed as a sign of pathological collinearity, as well as an indication that a model may be contaminated by common method bias. Therefore, if all VIFs resulting from a full collinearity test are equal to or lower than 3.3, the model can be considered free of common method bias. This study also conducted the analysis to test for the presence of multicollinearity through the tolerance values which is also 0.80 and above. Hair et al. (2011) SEM is equivalent to carrying out covariancebased SEM (CB-SEM suggested a threshold value of tolerance to be more than 0.20 . Hence, it was concluded that multicollinearity was not an issue in this study see Table 2.

As shown in Table 3, Cronbach's-alpha ranged from 0.791 to 0.898 , and composite reliability ranged from 0.857 to 0.918 for all five constructs respectively. The results exceed the minimum requirement of 0.7 , thus confirming the internal consistency and reliability of all constructs. The AVE for all constructs also exceeded 0.51 , which is larger than the minimum threshold of 0.50 , thus demonstrating convergent validity for all the constructs (Hair et al., 2012). An AVE of 0.50 means that the constructs account for $50 \%$ of the variance in its indicators, which is considered adequate (Hair 
Table 2: Descriptive Statistics of Study Variables $(\mathrm{N}=305)$

\begin{tabular}{lcccc}
\hline Constructs & Mean & Standard Deviation & VIF & Tolerance \\
\hline Merger \& & 3.96 & 0.41 & 1.19 & 0.83 \\
Acquisition & & 0.38 & 1.25 & 0.80 \\
Equity Issues & 4.09 & 0.44 & 1.14 & 0.87 \\
Intervention & 3.99 & 0.34 & Endogenous & Endogenous \\
Fin. Performance & 4.02 & 0.31 & Endogenous & Endogenous \\
Non-fin. Performance & 4.07 & & &
\end{tabular}

Table 3: Outer Loadings, CA, CR, AVE, VIF \& Tolerance

\begin{tabular}{|c|c|c|c|c|}
\hline Construct & Loading & CA & $\mathbf{C R}$ & AVE \\
\hline \multicolumn{5}{|l|}{ Merger and Acquisitions } \\
\hline $\begin{array}{l}\text { Merger \& acquisition of banks has improved the operational and } \\
\text { financing efficiency }\end{array}$ & 0.878 & 0.865 & 0.901 & 0.558 \\
\hline Merger \& acquisition has improved the competitive strength & 0.444 & & & \\
\hline Merger \& acquisition helps in reducing banking distress. & 0.888 & & & \\
\hline $\begin{array}{l}\text { Merger \& acquisition is a good source for generating more extensive } \\
\text { capital base }\end{array}$ & 0.881 & & & \\
\hline $\begin{array}{l}\text { Merger \& acquisition improved in absorbing shock or distressed in } \\
\text { banks }\end{array}$ & 0.496 & & & \\
\hline $\begin{array}{l}\text { Raising capital through merger \& acquisition is better than through } \\
\text { equity issues }\end{array}$ & 0.863 & & & \\
\hline There is a capital problem for involving in merger \& acquisition & 0.475 & & & \\
\hline $\begin{array}{l}\text { Banks meets up the recapitalization requirement through merger \& } \\
\text { acquisitions without any sharp practice }\end{array}$ & 0.846 & & & \\
\hline \multicolumn{5}{|l|}{ Equity Issues } \\
\hline $\begin{array}{l}\text { capital market has become a vital source for raising capital through } \\
\text { equity issues }\end{array}$ & 0.838 & 0.898 & 0.918 & 0.562 \\
\hline $\begin{array}{l}\text { Equity issues have effectively revitalized bank during the process of } \\
\text { recapitalization }\end{array}$ & 0.762 & & & \\
\hline $\begin{array}{l}\text { Equity issues have improved the competitive strength of my bank in } \\
\text { the industry }\end{array}$ & 0.784 & & & \\
\hline $\begin{array}{l}\text { Equity issues have effectively revealed the high potentials for } \\
\text { mobilizing the domestic capital }\end{array}$ & 0.898 & & & \\
\hline Equity issues are a better source for the large capital base & 0.508 & & & \\
\hline Recapitalization through equity issues helps to reduce banking distress & 0.762 & & & \\
\hline $\begin{array}{l}\text { Recapitalization through equity issues improve the public image of the } \\
\text { bank }\end{array}$ & 0.606 & & & \\
\hline $\begin{array}{l}\text { Recapitalization through equity issues improve the operational } \\
\text { efficiency }\end{array}$ & 0.874 & & & \\
\hline $\begin{array}{l}\text { The income generated during recapitalization process trough equity } \\
\text { issues has justified the recent recapitalization exercise }\end{array}$ & 0.625 & & & \\
\hline
\end{tabular}




\begin{tabular}{|c|c|c|c|c|}
\hline \multicolumn{5}{|l|}{ Intervention } \\
\hline Intervention has effectively increased the industry's public image & 0.740 & 0.865 & 0.891 & 0.512 \\
\hline Intervention has improved the capital capacity of the banking industry & 0.873 & & & \\
\hline Intervention was necessary to prevent banking sector distress & 0.584 & & & \\
\hline $\begin{array}{l}\text { Raising capital base through bail-out is more effective than equity } \\
\text { issues or merger \& acquisitions }\end{array}$ & 0.668 & & & \\
\hline Intervention has improved the operating and financing activities & 0.863 & & & \\
\hline Intervention has lead to stricter codes of corporate governance & 0.523 & & & \\
\hline $\begin{array}{l}\text { Intervention has become a better source for raising capital during } \\
\text { crises }\end{array}$ & 0.748 & & & \\
\hline $\begin{array}{l}\text { Capital base is inadequate even with the intervention (bail-out) in the } \\
\text { banking industry }\end{array}$ & 0.647 & & & \\
\hline \multicolumn{5}{|l|}{ Financial Performance } \\
\hline Return on Assets & 0.728 & 0.859 & 0.895 & 0.587 \\
\hline Return on Investment & 0.836 & & & \\
\hline Earnings Per Share & 0.797 & & & \\
\hline Profitability & 0.799 & & & \\
\hline Net profit margin & 0.737 & & & \\
\hline Deposit Mobilization & 0.689 & & & \\
\hline \multicolumn{5}{|l|}{ Non-Financial Performance } \\
\hline Market share & 0.745 & 0.791 & 0.857 & 0.546 \\
\hline Customer satisfaction & 0.728 & & & \\
\hline Employee satisfaction & 0.665 & & & \\
\hline Customer increasing rate & 0.762 & & & \\
\hline Customer complaints & 0.787 & & & \\
\hline
\end{tabular}

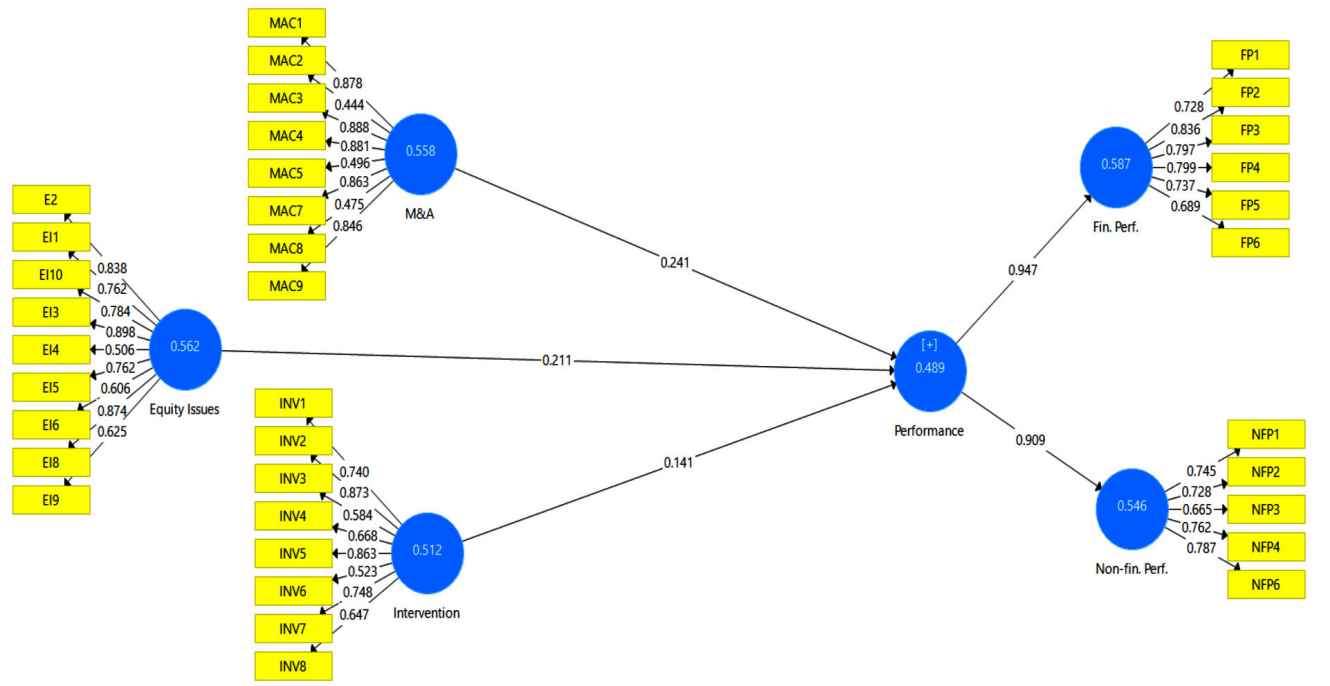

Figure 2: Measurement Model (First Order) 
et al., 2014). In other words, the latent construct explains half of the variance of its indicators and indicates adequate convergent validity (Hair et al., 2014).

Similarly, this study assessed discriminant validity using (Fornell-Lacker Criterion 1981) and Heterotrait-Monotrait (HTMT) to measure the extent to which one construct is actually different from another construct. Discriminant validity is established when the value of the square root of AVE of each construct is higher than the construct's highest correlation with any other latent construct (Henseler et al., 2009; Hair et al., 2014).

Hence, discriminant validity was evaluated in this study by comparing the square root of the AVE for each construct with the highest correlation of the latent construct in the matrix. Table 4 presents the assessment of the FornellLarcker criterion with the square root of the AVE (in boldface). The square root of AVE, when compared with the correlations, was higher than the correlations of any other constructs. Therefore, these results showed that the required level of the discriminant validity of the variables of this study had been achieved (Henseler et al., 2009; Hair et al., 2013).

However, Henseler et al. (2015) proposed heterotrait-monotrait (HTMT) ratio of correlation as another measure for discriminant validity. The authors showed that HTMT is able to achieve higher sensitivity rates ( $97 \%$ to $99 \%$ ) as compared to the Fornell-Lacker criterion. The HTMT criterion is defined as the mean value of the indicator correlations across constructs (i.e., the heterotrait-monotrait method correlations) relative to the (geometric) mean of the average correlations of indicators measuring the same construct (Sarstedt et al., 2017).

Based on previous research, Henseler et al. (2015) suggested a threshold value of 0.90. HTMT $\left(\right.$ HTMT $_{\mathbf{0 . 9 0}}$ ) value exceeding 0.90 suggests a lack of discriminant validity. Results in Table 5 show that all values are significantly below the threshold of 0.90 suggesting that all the constructs are explicitly independent of each other. Thus, the criterion of discriminant validity has been met.

Table 4: Results of Discriminant Validity Based on Fornell-Larcker Criterion

\begin{tabular}{llccccc}
\hline & & $\mathbf{1}$ & $\mathbf{2}$ & $\mathbf{3}$ & $\mathbf{4}$ & $\mathbf{5}$ \\
\hline $\mathbf{0 1}$ & Equity Issues & $\mathbf{0 . 7 5 0}$ & & & & \\
$\mathbf{0 2}$ & Financial Performance & 0.320 & $\mathbf{0 . 7 6 6}$ & & & \\
$\mathbf{0 3}$ & Intervention & 0.223 & 0.223 & $\mathbf{0 . 7 1 6}$ & & \\
$\mathbf{0 4}$ & Merger and Acquisitions & 0.249 & 0.302 & 0.188 & $\mathbf{0 . 7 2 0}$ & \\
$\mathbf{0 5}$ & Non-Financial Performance & 0.224 & 0.727 & 0.205 & 0.279 & $\mathbf{0 . 7 3 9}$ \\
\hline
\end{tabular}

Note: Entries shown in boldface represent the square root of the AVE (Measurement Model).

Table 5: Heterotrait-Monotrait Ratio of Correlations (HTMT) $(n=305)$

\begin{tabular}{lrcrcr}
\hline \multicolumn{1}{c}{ Constructs } & $\begin{array}{c}\text { Equity } \\
\text { Issues }\end{array}$ & $\begin{array}{c}\text { Financial } \\
\text { Performance }\end{array}$ & Intervention & $\begin{array}{c}\text { Merger and } \\
\text { Acquisition }\end{array}$ & $\begin{array}{c}\text { Non-Financial } \\
\text { Performance }\end{array}$ \\
\hline Equity Issue & & & & & \\
Fin. Performance & 0.346 & & & \\
Intervention & 0.244 & 0.237 & & \\
Merger \& Acquisition & 0.291 & 0.326 & 0.244 & 0.318 \\
Non-Fin. Performance & 0.266 & 0.860 & 0.236 & \\
\hline
\end{tabular}




\section{The Structural Model}

After establishing the measurement model, the reliability and validity of the model are ascertained, the next step was to assess the structural model. This involved evaluating the structural model's predictive abilities and relationships between the constructs. The fundamental criteria for evaluating a structural model in PLS-SEM are the significance of the path coefficients (Hair et al., 2014). A systematic model analysis of the structural model was carried out to provide a detailed understanding of the results and test the Hypotheses $H_{1}$ to $H_{4}$. In addition, a standard bootstrapping procedure with-5,000 bootstrap samples was used to assess the significance of the path coefficients (Henseler et al., 2009; Hair et al., 2017).

This study used a repeated indicator approach as this approach is the most frequently used method for estimating higher-order constructs in PLS (Wilson \& Henseler, 2007). In the repeated indicators approach, the manifest indicators of the first-order constructs are reused for the second-order construct (Riel et al., 2017). This study examined the effect of bank recapitalization on bank performance, where the performance treated as a hierarchical secondorder construct, which consists of both financial and non-financial performance as demonstrated by (Rapiah et al., 2016).

Figure 3 and Table 6 show the estimates for the full structural model, which includes recapitalization (merger and acquisition, equity issues and intervention) and bank performance (financial and non-financial). Figure 3 focused on the analysis of the hierarchical model, i.e., between the independent variables and the dependent variable (Hypotheses $H_{1}$ to $H_{3}$, and $H_{4}$ ). In Figure 3 second-order reflectivereflective was introduced, and analysis of the relationship between the independent variable (recapitalization) and the dependent variable (bank performance) (Hypotheses $\mathrm{H}_{4}$ ) was carried out. Table 6 shows the details of the results.

Hypothesis $H_{1}$ was developed to examine the relationship between merger and acquisitions and the performance of the Nigerian banking sector. Results in Figure 3 and Table 6 show a significant positive effect of mergers and acquisitions on the performance of the banking sector where $\beta=0.213, t=3.931$, and $p<0.000$, supporting Hypothesis $H_{l}$. This confirmed the initial prediction of $\mathbf{H}_{\mathbf{1}}$. Likewise, Hypothesis $\boldsymbol{H}_{2}$ was developed to examine the relationship between equity issues and the performance of the Nigerian banking sector. Results in Figure 3 and Table 6 show that equity issues and bank performance had a significant positive relationship with $\beta=0.180, \mathrm{t}=3.443$, and $\mathrm{p}<$ 0.000 , supporting Hypothesis $H_{2}$. This is also confirmed the initial postulation of $\mathbf{H}_{2}$.

Furthermore, Hypothesis $\mathrm{H}_{3}$ was developed to examine the relationship between intervention and the performance of the Nigerian banking sector. As shown in Table 6, there is a positive

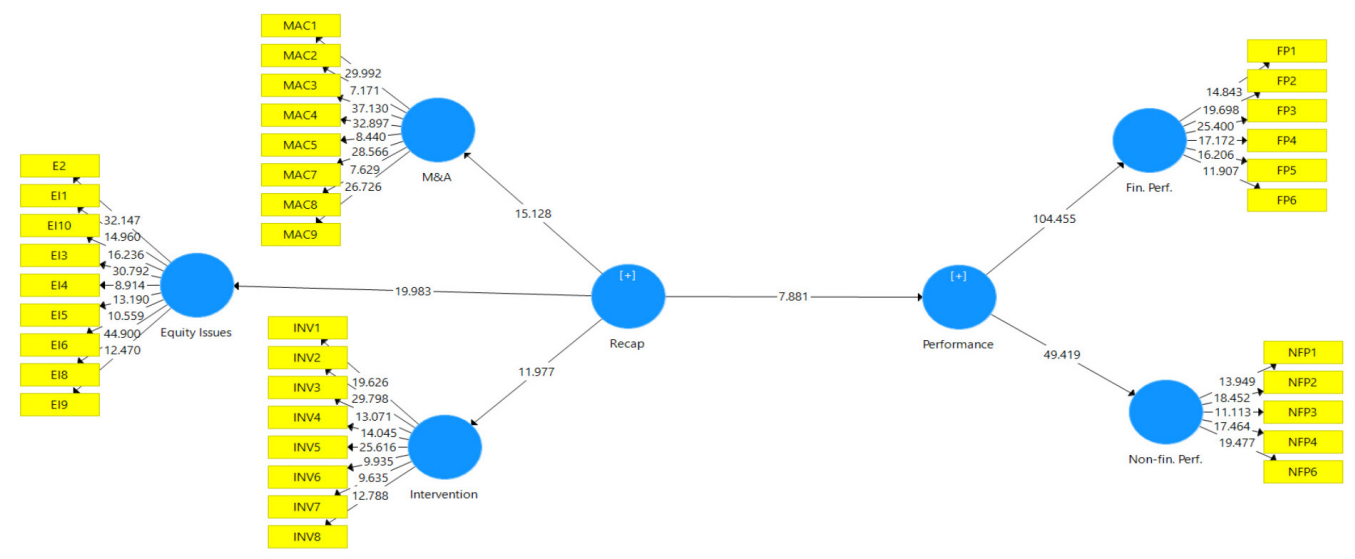

Figure 3: Structural Model (Second Order) 
Table 6: Results of Hypotheses Testing (Direct Relationships)

\begin{tabular}{clccccc}
\hline Hypothesis & \multicolumn{1}{c}{ Relationship } & $\boldsymbol{\beta}$ & $\begin{array}{c}\text { Stand } \\
\text { Dev }\end{array}$ & T Stat & P Values & Decision \\
\hline $\mathbf{H}_{1}$ & Merger \& Acquisition -> Perf. & 0.213 & 0.054 & 3.931 & 0.000 & Supported \\
$\mathbf{H}_{2}$ & Equity Issues -> Perf. & 0.180 & 0.052 & 3.443 & 0.001 & Supported \\
$\mathbf{H}_{3}$ & Intervention-> Perf. & 0.120 & 0.045 & 2.684 & 0.008 & Supported \\
$\mathbf{H}_{4}$ & Recapitalization -> Perf. & 0.322 & 0.048 & 6.869 & 0.000 & Supported \\
\hline
\end{tabular}

Note: In two-tailed test of significance $p<0.01^{* * *}, p<0.05^{* *}, p<0.1 *$.

significant association between the intervention and bank performance with $\beta=0.120, t=2.684$, and $p<0.008$, indicating support for Hypothesis $\mathbf{H}_{3}$. Furthermore, Hypothesis $\boldsymbol{H}_{4}$ was developed to examine if there is a relationship between recapitalization and performance in the Nigerian banking sector. Results in Figure 3 and Table 6 Sustainability show that recapitalization and bank performance have a significant positive relationship with $\beta=0.322, t=6.869$, and $p<$ 0.000 supporting Hypothesis $\mathbf{H}_{4}$ is statistically significant.

\section{Conclusion}

The aim of the study was to evaluate the effects of bank recapitalization and its impact on bank performance. The model was developed and tested to verify the hypotheses with respect to dimensions of recapitalization (i.e., merger and acquisition, equity issues and intervention) on banking sector performance. This study is amongst the first to empirically investigate the effect of bank recapitalization and its dimensions on the performance of the Nigerian banking sector. This study has demonstrated that bank recapitalization mirrors positive and significant effects on bank performance. Several extant studies have examined the bank recapitalization from a unidimensional perspective Adedeji et al. (2015), Beccalli et al. (2016), Etri et al. (2016) and Tomec and Jagrič, (2017) these could both be limiting or misleading. This is because they failed to include the insights of all dimensions of bank recapitalization and how these various dimensions relate to bank performance proxies (i.e., financial and non-financial performance). It is deemed misleading as it may guide the readers to develop a perception that bank recapitalization mainly demonstrates a particular kind of effect on bank performance.

Similarly, this study has empirically investigated the effect of merger and acquisition on bank performance and found that mergers and acquisitions have a significant positive effect on the bank performance. These results are in agreement with the discourse of several studies that have also explored the effect of merger and acquisition on the bank performance (Abdulazeez et al., 2016; Arena \& Dewally, 2017; Christine \& Jagongo, 2018; Souza \& Gartner, 2019). This also confirms that, the study's position and prior argument raised by Hassen et al. (2018) that in the long run merger and acquisition achieve all their aims. Similarly, this study also demonstrated that equity issues have a significant positive relationship with bank performance. This is consistent with the study findings of Keeley (1989) and Beccalli et al. (2018) which indicates that equity issue has a positive and significant impact on bank performance, thus, complementing the position of Bessler and Thies (2007) who emphasized that, the abnormal returns and performances was due to opportunity to raise additional funds in the equity market for subsequent years.

Likewise, our study also demonstrated that intervention displays a significant positive effect on a bank's performance. The research findings of this study support the previous research findings of Cordella and Yeyati (2003), Hryckiewicz (2014b) and Berger et al. (2016), which indicated the importance of regulatory arrangements to restore the confidence to achieve the sustainable banking sector performance. 
Additionally, our result showed that bank recapitalization has a stronger influence on financial than non-financial performance.

This study is a pioneering research in the field of empirical analyses regarding the effect of bank recapitalization on the performance of the banking sector. Future research should study other factors that may influence the variables in the proposed model; for instance, future researchers should consider blanket guarantee and debt restructuring as part of bank recapitalization in their study. It would also be useful to analyze other potential moderators due to contradictory results in the previous findings.

\section{Acknowledgements}

This research was supported by Azman Hashim International Business School, Universiti Teknologi Malaysia, Johor Bahru, Malaysia. The authors acknowledge the helpful comments of anonymous reviewers and their valuable suggestions. The authors would also like to thank the editors of the Journal of Sustainability Science and Management.

\section{References}

Abdul-Rasheed, A., Babaita, I. S., \& Yinusa, M. A. (2012). Fraud and its implication for bank performance in Nigeria. International Journal of Asian Social Science, 2(4), 382387.

Abdulazeez, D. A., Suleiman, O., \& Yahaya, A. (2016). Impact of merger and acquisitions on the financial performance of deposit money banks in Nigeria. Arabian Journal of Business and Management Review, 5(4$5)$.

Acha, I. (2012). Microfinance banking in Nigeria: Problems and prospects. International Journal of Finance and Accounting, 1(5), 106-111.

Acharya, V., Engle, R., \& Richardson, M. (2012). Capital shortfall: A new approach to ranking and regulating systemic risks.
American Economic Association Capital, 102(3), 58-64.

Acharya, V. V., \& Steffen, S. (2015). The "greatest" carry trade ever? Understanding Eurozone bank risks. Journal of Financial Economics, 115(2), 215-236.

Adebambo, H. O., Ashari, H., \& Nordin, N. (2015). An empirical study on the influence of sustainable environmental manufacturing practice on firm performance. Journal of Sustainability Science and Management, 10(2), 42-51.

Adedeji, Babatunde, \& Adekanye. (2015). Recapitalization policy and performance of banks in Nigeria (2006-2013). International Journal of Economics, Commerce and Management, III(4), 1-12.

Adepoju, B. (2013). Stock market performance of some selected Nigerian commercial banks amidst economic turbulence. Journal of Economics and Sustainable Development, 4(13), 170-182.

Aduloju, S. A., Awoponle, A. L., \& Oke, S. A. (2008). Recapitalization, mergers, and acquisitions of the Nigerian insurance industry. The Journal of Risk Finance, 9(5), 449-466.

Ahmed, I., \& Manab, N. A. (2016). Moderating effects of board equity ownership on the relationship between enterprise risk management and firms performance: Data screening and measurement model. Research Journal of Finance and Accounting (Online), 7(6), 163-187.

Al-Magharem, A. A. S., Haat, M. H. C., Hashim, H. A., \& Ismail, S. (2019). Corporate governance and loan loss provisions: A review. Journal of Sustainability Science and Management, 14(4), 228-241.

Alford, D. (2011). Nigerian banking reform: Recent actions and future prospects. Retrieved from https:/www.proshareng.com/articles/ The Economy/Nigerian-banking-reform:Recent-actions-and-future-prospects/2268 
Aman, H., \& Miyazaki, H. (2009). Valuation effects of new equity issues by banks: Evidence from Japan. Applied Financial Economics, 19(8), 635-645.

Antony, J. P., \& Bhattacharyya, S. (2010). Measuring organizational performance and organizational excellence of SMEs - Part 1: A conceptual framework. Measuring Business Excellence, 14(2), 3-11.

Arena, M. P., \& Dewally, M. (2017). Investment bank expertise in cross-border mergers and acquisitions. Journal of Financial Research, 40(1), 81-112.

Artino, A. R., Rochelle, J. S., Dezee, K. J., \& Gehlbach, H. (2014). Developing questionnaires for educational research: AMEE Guide No. 87. Journal Medical Teacher, 1(87), 463-474.

Ashraf, B. N., Arshad, S., \& Hu, Y. (2016). Capital regulation and bank risk-taking behavior: Evidence from Pakistan. International Journal of Financial Studies, 4(16), 1-20.

Ashraf, N. B., Zheng, C., Jiang, C., \& Qian, N. (2020). Capital regulation, deposit insurance and bank risk: International evidence from normal and crisis periods. Research in International Business and Finance, 52, 101188.

Avkiran, N. K. (2018). Partial least squares structural equation modeling, A recent advances in banking and finance. Gewerbestrasse Cham, Switzerland: Springer International Publishing.

Aybar, B., \& Ficici, A. (2009). Cross-border acquisitions and firm value: An analysis of emerging-market multinationals. Journal of International Business Studies, 40(8), 1317-1338.

Babbie, E. (2008). The basics of social research (4th ed.). https://doi.org/10.1192/bjp.11

Bayazitova, D., \& Shivdasani, A. (2012). Assessing TARP. The Review of Financial Studies, 25(2), 377-407.
Beccalli, E., \& Frantz, P. (2016). Why are some banks recapitalized and others taken over? Journal of International Financial Markets, Institutions and Money, 45(2), 79-95.

Beccalli, E., Frantz, P., \& Lenoci, F. (2016). Hidden effects of bank recapitalizations. London School of Economics, 44(1), 1-38.

Beccalli, E., Frantz, P., \& Lenoci, F. (2018). Hidden effects of bank recapitalizations. Journal of Banking and Finance, 2(3), 1-27.

Berger, A. N., \& Bouwman, C. H. S. (2013). How does capital affect bank performance during financial crises $\alpha$. Journal of Financial Economics, 109(1), 146-176.

Berger, A. N., Bouwman, C. H. S., Kick, T., \& Schaeck, K. (2016). Bank liquidity creation following regulatory interventions and capital support. Journal of Financial Intermediation, 26(1), 115-141.

Bertrand, O., \& Betschinger, M. A. (2012). Performance of domestic and cross-border acquisitions: Empirical evidence from Russian acquirers. Journal of Comparative Economics, 40(3), 413-437.

Bessler, W., \& Kurmann, P. (2014). Bank risk factors and changing risk exposures: Capital market evidence before and during the financial crisis. Journal of Financial Stability, 13(1), 151-166.

Bessler, W., \& Thies, S. (2007). The long-run performance of initial public offerings in Germany. Managerial Finance, 33(6), 420441.

Bhagat, S., Malhotra, S., \& Zhu, P. C. (2011). Emerging country cross-border acquisitions: Characteristics, acquirer returns and crosssectional determinants. Emerging Markets Review, 12(3), 250-271.

Bhaumik, S. K., \& Selarka, E. (2012). Does ownership concentration improve M\&A outcomes in emerging markets? Evidence from India. Journal of Corporate Finance, 18(4), 717-726. 
Bibi, U., Balli, H. O., Matthews, C. D., \& Tripe, D. W. L. (2018). New approaches to measure the social performance of microfinance institutions (MFIs). International Review of Economics and Finance, 53(2), 88-97.

Black, L. K., \& Hazelwood, L. N. (2013). The effect of TARP on bank risk-taking. Journal of Financial Stability, 9(4), 790-803.

Bremser, W. G., \& Chung, Q. B. (2005). A framework for performance measurement in the e-business environment. Electronic Commerce Research and Applications, 4(4), 395-412.

CBN C. B. of N. (2010). CBN scope, conditions and minimum standards for specialized institutions regulations. Abuja.

Chiakelu, E. (2010). Recapitalization of the banks in Nigeria. Aprica Political and Economic Strategic Centre.

Chin, W. W. (1998). The partial least squares approach to structural equation modeling. In Modern methods for business research. New Jersey: Laurence Erlbaum Associates.

Christine, O., \& Jagongo, A. (2018). Mergers and acquisitions on financial performance among selected commercial banks in Kenya. International Academic Journal of Economics and Finance, 3(1), 1-23.

Coates, J. C., \& Scharfstein, D. S. (2009). Lowering the cost of bank recapitalization. Yale Journal on Regulation, 26(2), 372-389.

Cooper, D. R., \& Schindler, P. S. (2014). Business research methods (12th ed.). New Jersey: McGraw-Hill' s/Irwin Company, Inc.

Cordella, T., \& Yeyati, E. L. (2003). Bank bailouts: Moral hazard vs. value effect. Journal of Financial Intermediation, 12(4), 300330 .

Creswell, J. W. (2014). Research design: Qualitative, quantitative, and mixed methods approaches (4th ed.). Nebraska, USA: SAGE Publications, Inc.
Dam, L., \& Koetter, M. (2012). Bank bail-outs and moral hazard: Evidence from Germany. Review of Financial Studies, 25(8), 23432380 .

De Caux, R., McGroarty, F., \& Brede, M. (2017). The evolution of risk and bail-out strategy in banking systems. Physica A: Statistical Mechanics and Its Applications, 468, 109-118.

De-Vaus, D. A. (2002). Surveys in social research (5th ed.). Australia.

Ding, C. G., Wu, C. H., \& Chang, P. L. (2013). The influence of government intervention on the trajectory of bank performance during the global financial crisis: A comparative study among Asian economies. Journal of Financial Stability, 9(4), 556-564.

Donou-Adonsou, F., \& Sylwester, K. (2017). Growth effect of banks and microfinance: Evidence from developing countries. Quarterly Review of Economics and Finance, 64(4), 44-56.

Duchin, R., \& Sosyura, D. (2012). The politics of government investment. Journal of Financial Economics, 106(1), 24-48. https:// doi.org/10.1016/j.jfineco.2012.04.009

Duchin, R., \& Sosyura, D. (2014). Safer ratios, riskier portfolios: Bank's response to government aid. Journal of Financial Economics, 113(1), 1-28.

El-Chaarani, H., \& El-Abiad, Z. (2019). Analysis of capital structure and performance of banking sector in Middle East Countries. International Journal of Economics and Financial Issues, 9(2), 1-11.

Ernovianti, E., \& Ahmad, N. H. (2017). Influence of external forces on bank recapitalization: An evidence of banks in IMT-GT economic region. Journal of Accounting and Finance in Emerging Economies, 3(2), 123-130.

Etri, E., Nor, H., \& Mazlan, R. A. (2016). Recapitalization effectiveness and performance of banks in Malaysia. Information Management and Business Review, 8(4), 6-12. 
Ezeoha, A. E. (2011). Banking consolidation, credit crisis and asset quality in a fragile banking system: Some evidence from Nigerian data. Journal of Financial Regulation and Compliance, 19(1), 33-44.

Fadun, S. O. (2014). Financial inclusion, tool for poverty alleviation and income redistribution in developing countries: Evidences from Nigeria. Academic Research International, 5(3), 137-146.

Fernandes, C., Farinha, J., Martins, F. V., \& Mateus, C. (2016). Supervisory boards, financial crisis and bank performance: Do board characteristics matter? Journal of Banking Regulation, 18(4), 310-337.

Flannery, M. (1998). Using market information in prudential bank supervision: A review of the US empirical evidence. Journal of Money, Credit and Banking, 30(3), 273305.

Fornell, C., \& Larcker, D. (1981). Evaluating structural equation models with unobservable variables and measurement error. Journal of Marketing Research, 18(1), 39-50.

Francis, B. B., Hasan, I., \& Wu, Q. (2012). Do corporate boards affect firm performance? New evidence from the financial crisis. SSRN Electronic Journal, 26(7), 1-58.

Georgakopoulos, N. L. (2017). PIRG doldrums: Exit via overrecapitalization. European Journal of Law and Economics, 43(2), 317-332.

Gitau, E. W., \& Samson, N. G. (2016). Effect of financial fraud on the performance of commercial banks: A case study tier 1 banks in Nakuru town, Kenya. International Journal of Economics, Commerce and Management, IV(12), 142-157.

Gropp, R., Hakenes, H., \& Schnabel, I. (2011). Competition, risk-shifting, and public bail-out policies. The Review of Financial Studies, 24(6), 1916-1943.

Groves, R., Fowler, F. J., Mick Couper, James M. Lepkowski, Eleanor Singer, \& Tourangea,
R. (2004). Survey methodology (4th ed.). New Jersey: A John Wiley \& Sons, Inc., Publication.

Haggège, M., Gauthier, C., \& Rüling, C. C. (2017). Business model performance: Five key drivers. Journal of Business Strategy, 38(2), 6-15.

Hair, Sarstedt, M., Ringle, C. M., \& Mena, J. A. (2012). An assessment of the use of partial least squares structural equation modeling in marketing research. Journal of the Academy of Marketing Science, 40(3), 414-433.

Hair, J., Sarstedt, M., Hopkins, L., \& Kuppelwieser, V. G. (2014). Partial least squares structural equation modeling (PLS-SEM) An emerging tool in business research. European Business Review, 26(2), 106-121.

Hair, Joe F., Ringle, C. M., \& Sarstedt, M. (2011). PLS-SEM: Indeed a silver bullet. The Journal of Marketing Theory and Practice, 19(2), 139-152.

Hair, Joseph F., Hult, G. T. M., Ringle, C. M., \& Rstedt, M. S. (2014). A primer on partial least squares structural equation modeling (PLS-SEM). In European Business Review.

Hair, Joseph F., Ringle, C. M., \& Sarstedt, M. (2013). Editorial, partial least squares structural equation modeling: Rigorous applications, better results and higher acceptance. Long Range Planning, 46(1), $1-12$.

Hair, Joseph F, Hult, T., Ringle, C. M., \& Sarstedt, M. (2017). A primer on partial least squares structural equation modeling (2nd ed.). Los Angeles: SAGE Publications, Inc.

Hair Jr, J. F., Hult, G. T. M., Ringle, C., \& Sarstedt, M. (2014). A primer on partial least squares structural equation modeling (PLS-SEM). Los Angeles: SAGE Publications.

Hassen, T., Fakhri, I., Bilel, A., Wassim, T., \& Faouzi, H. (2018). Dynamic effects of 
mergers and acquisitions on the performance of commercial European banks. Journal of the Knowledge Economy, 9(3), 1032-1048.

Henseler, J., Ringle, C. M., \& Sarstedt, M. (2015). A new criterion for assessing discriminant validity in variance-based structural equation modeling. Journal of the Academy of Marketing Science, 43(1), 115-135.

Henseler, J., Ringle, C. M., \& Sinkovics, R. R. (2009a). The use of partial least squares path modeling in international marketing. Advances in International Marketing, 20(2), 277-319.

Henseler, J., Ringle, C. M., \& Sinkovics, R. R. (2009b). The use of partial least squares path modeling in international marketing. Advances in International Marketing, 20(2), 277-319.

Hryckiewicz, A. (2014a). The problem with government interventions: The wrong banks, inadequate strategies, or ineffective measures? International Journal of Banking and Finance, 15(2), 1-44.

Hryckiewicz, A. (2014b). What do we know about the impact of government interventions in the banking sector? An assessment of various bail-out programs on bank behavior. Journal of Banking and Finance, 46(1), 246-265.

Hulland, J. (1999). Use of partial least squares (PLS) in strategic management research: A review of four recent studies. Strategic Management Journal, 20(2), 195-204.

Hussain, M., \& Hoque, Z. (2002). Understanding non-financial performance measurement practices in Japanese banks. Accounting, Auditing \& Accountability Journal, 15(2), 162-183.

Islam, Z., Ahmed, S. U., \& Hasan, I. (2012). Corporate social responsibility and financial performance Linkage: Evidence from the banking sector of Bangladesh. Journal of Organizational Management, 1(1), 14-21.
Izuchukwu, O.-O., Long, W., Shehu, A. A., \& Olufemi, E. A. (2014). Employee's perception of change effect as a competitive advantage on Nigeria banking industry: An empirical analysis. Procedia - Social and Behavioral Sciences, 150, 281-290.

Joash, G. O., \& Njangiru, M. J. (2015). The effect of mergers and acquisitions on financial performance of banks: A survey of commercial banks in Kenya. International Journal of Innovative Research \& Development, 4(8), 101-113.

Kaplan, R. S., \& Norton, D. P. (2001). Transforming the balanced scorecard from performance measurement to strategic management: Part I. Accounting Horizons, 15(1), 87-104.

Kaplan, Robert S., \& Norton, D. P. (1996). The Balanced Scorecard: Translating Strategy Into Action. In Proceedings of the IEEE (Vol. 85).

Keeley, M. (1989). The stock price effects of bank holding company security issuance. Economic Review $\square$ Federal Reserve Bank of San Francisco, 1(3), 3-19.

Kemal, M. U. (2011). Post-merger profitability: A case of royal bank of Scotland (RBS). International Journal of Business and Social Science, 2(5), 157-162.

Kiliç, M. (2011). Cross-border bank acquisitions and banking sector performance: An empirical study of Turkish banking sector. Procedia - Social and Behavioral Sciences, 24, 946-959. https://doi.org/10.1016/j. sbspro.2011.09.028

Kock, N. (2015). Common method bias in PLS-SEM: A full collinearity assessment approach. International Journal of E-Collaboration, 11(4), 1-10.

Krejcie, R. V., \& Morgan, D. W. (1970). Determining sample size for research activities. Educational and Psychological Measurement, 38, 607-610.

Lakstutiene, A., Stankeviciene, J., Norvaisiene, R., \& Narbutiene, J. (2015). The impact 
of acquisitions on corporate performance results during the period of economic slowdown: Case of Lithuania. Procedia Social and Behavioral Sciences, 213, 455460.

Lebedev, S., Peng, M. W., Xie, E., \& Stevens, C. E. (2015). Mergers and acquisitions in and out of emerging economies. Journal of World Business, 50(4), 651-662.

Liao, A., \& Williams, J. (2008). Do win-win outcomes exist? A study of cross-border M\&A transactions in emerging markets. Journal of Economic Literature, 50(2), 274-296.

Mackenzie, S. B., Podsakoff, P. M., \& Podsakoff, N. P. (2011). Construct measurement and validation procedures in MIS and behavioral research: Integrating new and existing techniques. MIS Quarterly, 35(2), 293-334.

Meghouar, H., \& Sbai, H. (2013). The Performance of bank mergers and acquisitions: The case of the commercial bank of Morocco and wafabank. La Revue Gestion et Organisation, 5(1), 71-78. https://doi.org/10.1016/j.rgo.2013.12.002

Mehran, H., \& Thakor, A. (2011). Bank capital and value in the cross-section. Review of Financial Studies, 24(4), 1019-1067.

Miozzo, M., DiVito, L., \& Desyllas, P. (2016). When do acquirers invest in the R\&D assets of acquired science-based firms in cross-border acquisitions? The role of technology and capabilities similarity and complementarity. Long Range Planning, 49(2), 221--240.

Mishkin, F. S. (2007). Housing and the monetary transmission mechanism. Journal of Management, 4(2), 655-670. https://doi. org/10.3386/w13518

Moskowitz, M. (1972). Choosing socially responsible stocks. Business and Society, 1, $71-75$

Najmi, M., Rigas, J., \& Fan, I.-S. (2005). A framework to review performance measurement systems. Business Process Management Journal, 11(2), 109-122.

Nakashima, K. (2016). An econometric evaluation of bank recapitalization programs with bank- and loan-level data. Journal of Banking and Finance, 63(2), $1-24$.

NDIC. (2011). Resolution of failing banks through the establishment of bridge. Lagos.

Neely, A. (2007). Business performance measurement: Unifying theories and integrating practice (2nd ed.). New York: Cambridge University Press.

Nicholson, R. R., \& Salaber, J. (2013). The motives and performance of cross-border acquirers from emerging economies: Comparison between Chinese and Indian firms. International Business Review, 22(6), 963-980.

Odunsi, W. (2018). The Nigerian stock exchange (NSE). Daily Post News Paper, p. 1.

Ogbeibu, S., Senadjki, A., \& Gaskin, J. (2018). The moderating effect of benevolence on the impact of organizational culture on employee creativity. Journal of Business Research, 90(November 2017), 334-346.

Oleka, \& Mgbodile. (2014). Recapitalization reform and bank's performance: Empirical evidence from Nigeria. Research Journal of Finance and Accounting, 5(6), 96-101.

Patel, R. (2018). Pre \& post-merger financial performance: An Indian perspective. Journal of Central Banking Theory and Practice, 7(3), 181-200.

Petrovic, A., \& Tutsch, R. (2009). National rescue measures in response to the current financial crisis. Journal of Economic Structures, 5(2), 1-10. http://papers.ssrn. com/sol3/papers.cfm?abstract_id $=1430489$

Philippon, T., \& Schnabl, P. (2010). Efficient bank recapitalization. The Journal of Finance, 3(1), 1-54.

Porter, S. R. (2004). Raising response rates: What works? New Directions for Institutional 
Research, 2004(121), 5-21. https://doi. org/10.1002/ir.97

Potter, G., \& Srinivasan, D. (2005). Association of nonfinancial performance measures with the financial performance of a lodging chain. Journal of Applied Business Research, 46(4), 394-412.

Rapiah, M., Jamil, M. C. Z., \& Aliyu, N. S. (2016). Does performance measurement system influence firm's performance? Evidence from Nigerian bailed-out banks. The Social Science, 11(6), 7143-7147.

Repullo, R., \& Suarez, J. (2013). The procyclical effects of bank capital regulation. Review of Financial Studies, 26(2), 452-490.

Rettab, B., Brik, A. Ben, \& Mellahi, K. (2009). A study of management perceptions of the impact of corporate social responsibility on organizational performance in emerging economies: The case of Dubai Belaid Rettab. Journal of Business Ethics, 89(1), 371-390. https://doi.org/10.1007/s10551008-0005-9

Rhoades, S. A. (1996). Bank mergers and industrywide structure. Journal of Empirical Finance, 2(1), 1-30.

Riel, A. V., Henseler, J., Kemény, I., \& Sasovova, Z. (2017). Estimating hierarchical constructs using consistent partial least squares: The case of second-order composites of common factors. Industrial Management \& Data Systems, 117(3), 459-477.

Rilwan, A. (2018). CBN revokes Skye Bank's license. The Nation, pp. 1-2.

Rose, A. K., \& Wieladek, T. (2012). Too big to fail: Some empirical evidence on the causes and consequences of public banking interventions in the UK. Journal of International Money and Finance, 31(8), 2038-2051.

Saeidi, P., Sofian, S., \& Siti-Zaleha, A.-R. (2014). A proposed model of the relationship between enterprise risk management and firm performance. International Journal of
Information Processing and Management, 5(2), 70-80.

Salkind, N. J. (2007). Encyclopaedia of measurement and statistics. Kansas: University of Kansan.

Salleh, H. S., \& Nor-Azila, N. M. (2018). Moderating effect of self-efficacy on the relationship between consumer attitude and willingness to consume healthy food. Journal of Sustainability Science and Management, 1(4), 33-50. http:// jssm.umt.edu.my/wp-content/uploads/ sites/51/2018/07/bab-3.pdf

Sanusi, L. (2010). The Nigerian banking industry: What went wrong and the way forward.

Sanusi, L. (2011). Global financial meltdown and the reforms in the Nigerian banking sector. Journal of Applied Statistics, 2(1), 93-108.

Sarstedt, M., Ringle, C. M., \& Hair, J. F. (2017). Handbook of Market Research. https://doi. org/10.1007/978-3-319-05542-8

Sarstedt, M., Ringle, C. M., Smith, D., Reams, R., \& Hair, J. F. (2014). Partial least squares structural equation modeling (PLS-SEM): A useful tool for family business researchers. Journal of Family Business Strategy, 5(1), 105-115.

Shanmugam, B., \& Nair, M. (2004). Mergers and acquisitions of banks in Malaysia. Managerial Finance, 30(4), 1-18.

Shehu, N. A., Jamil, M. Z., \& Mohamed, R. (2014). The mediating role of management control system in the relationship between corporate governance and the performance of bailed-out banks in Nigeria. Social and Behavioral Sciences, 16, 613-620.

Soludo, C. (2004). Consolidating the Nigerian banking industry to meet the development challenges of the 21st century. Abuja.

Souza, J. G. D. M., \& Gartner, I. R. (2019). Market reaction to bank merger and acquisition events in Brazil: An analysis 
of the effects of market waves. Journal of Banks and Bank Systems, 30(80), 234-251.

Sufian, F., \& Shah Habibullah, M. (2013). Financial sector consolidation and competition in Malaysia: An application of the Panzar-Rosse method. Journal of Economic Studies, 40(3), 390-410.

Tomec, M., \& Jagrič, T. (2017). Does the amount and time of recapitalization affect the profitability of commercial banks? Czech Journal of Economics and Finance, 67(4), 318-341.

Vulanovic, M. (2017). SPACs: Post-merger survival. Managerial Finance, 43(6), 679699.
Wilson, B., \& Henseler, J. (2007). Modeling reflective higher-order constructs using three approaches with pls path modeling: A Monte Carlo comparison. Journal of Business and Psychology, 16(2), 2-11.

Wu, H., Tzeng, G., \& Chen, Y. (2009). A fuzzy MCDM approach for evaluating banking performance based on balanced scorecard. Expert Systems With Applications, 36(6),

Yusupov, N. (2012). Microcredit and development in an occupational choice model. Economics Letters, 117(3), 820823. 